\title{
PENGARUH MANAJEMEN LABA, UKURAN DEWAN KOMISARIS, KEPEMILIKAN INSTITUSIONAL, DAN KUALITAS AUDIT TERHADAP BIAYA MODAL PERUSAHAAN
}

(Studi pada Badan Usaha Milik Negara Periode 2010 - 2012)

Oleh:

Denny Andriana

(Program Studi Akuntansi Universitas Pendidikan Indonesia)

Renny Friska

(Program Studi Akuntansi Universitas Pendidikan Indonesia)

\begin{abstract}
This research aims to determine the effect of earnings management, board of commissioners size, institutional ownership, and quality audits of the cost of capital for Badan Usaha Milik Negara (BUMN) in the period 2010-2012. Purposive sampling method used in determining the sample resulted in 23 of 141 observations were carried out on state-owned enterprises listed on BUMN for the period 2010-2012. The data analysis technique used in this research is multiple regression. The test results indicate that earnings management and institutional ownership partially negatively affect the cost of capital. The test results indicate that earnings management and institutional ownership partially negatively affect the cost of capital.
\end{abstract}

Keywords: Earnings Management, board of commissioners size institutional ownership, quality audits, cost of capital.

\section{Pendahuluan}

Kinerja Badan Usaha Milik Negara (BUMN) di Indonesia periode tahun 2010-2012 secara umum mengalami peningkatan. Salah satu indikatornya terlihat pada kinerja keuangan BUMN yang ditunjukkan dari adanya peningkatan total laba bersih sejumlah 141 BUMN seperti yang ditunjukan pada tabel 1 di bawah ini:

Tabel 1

Kinerja Keuangan BUMN

\begin{tabular}{|l|c|c|c|}
\hline & $\begin{array}{c}2010 \text { (Audited) } \\
\text { (Rp. Trilyun) }\end{array}$ & $\begin{array}{c}2011 \text { (Audited) } \\
\text { (Rp. Trilyun) }\end{array}$ & $\begin{array}{c}2012 \text { (Audited) } \\
\text { (Rp. Trilyun) }\end{array}$ \\
\hline Jumlah BUMN & 141 & 141 & 141 \\
\hline Total Aset & 2.341 & 2.947 & 3.400 \\
\hline Total Kewajiban & 1.771 & $2.258,36$ & $2.600,8$ \\
\hline Total Ekuitas & 570 & 688,640 & 799,20 \\
\hline Total Penjualan & 964 & $1.378,26$ & 1.538 \\
\hline Total Laba BUMN & 102,4 & 115,6 & 140,4 \\
\hline Rugi BUMN & $23,9(28$ BUMN) & $10,4(23$ BUMN) & 2,27 (19 BUMN) \\
\hline LabaBersih BUMN & 78,5 & 105,2 & 138,1 \\
\hline
\end{tabular}

Sumber : Kementerian BUMN (bumn.go.id), LAKIP BUMN, data diolah. 
Walaupun terlihat adanya peningkatan laba bersih keuangan BUMN selama periode 2010 hingga 2012, manajemen BUMN dinilai masih kurang efektif dan efisien dalam menentukan langkah-langkah strategis. Hal ini dapat dilihat dari rasio kinerja BUMN tahun 2012 yang diukur dengan menggunakan rasio Return on Asset (ROA) yang menunjukkan nilai sebesar 4\%. Rasio sebesar $4 \%$ tersebut menjelaskan bahwa dengan nilai total aset BUMN di tahun 2012 sebesar Rp. 3.400 Trilyun, ternyata hanya mampu menghasilkan laba sebesar Rp. 140,4 Trilyun.

Sementara tingkat pengembalian dalam bentuk biaya modal berbanding terbalik dengan biaya riil yang harus dikeluarkan oleh BUMN untuk mendapatkan dana investasi. Nilai tingkat pengembalian tersebut di tahun 2012 mencapai $241 \%$ (data 23 BUMN, diolah) yang menunjukkan bahwa BUMN memiliki risiko bisnis yang tinggi.

Risiko bisnis yang tinggi ini dapat disebabkan karena adanya konflik keagenan yang dapat menimbulkan kondisi asimetri informasi, yaitu kondisi yang mencerminkan ketidak-seimbangan perolehan informasi antara pihak manajemen dengan pihak pemegang saham (Richardson, 1998, dalam Yunior, 2009). Ketika asimetri informasi tinggi, stakeholders tidak memiliki akses atas informasi yang relevan untuk mengawasi tindakan manajer. Kondisi ini memberikan peluang dilakukannya manajemen laba.

Selama periode 2010 hingga 2012, terlihat adanya kecenderungan manajemen BUMN melakukan kebijakan manajemen laba dengan menurunkan laba periode berjalan. Pada tahun 2012 saja misalnya, laba BUMN rata-rata menurun hingga $26,50 \%$ terhadap penjualan. Motif manajemen melakukan manajemen laba ialah untuk memperoleh pendanaan eksternal dengan biaya modal yang murah. Semakin tinggi tingkat manajemen laba dalam menurunkan laba perusahaan, maka akan semakin rendah pula risiko imbal hasilnya.

Meskipun bisnis BUMN memiliki risiko yang tinggi, investor tetap saja menanamkan modalnya. Hal ini karena kepemilikan institusional yang berasal dari unsur pemerintah dijajaran pemegang saham BUMN, baik itu sebagai komisaris maupun direksi, diyakini dapat memberikan jaminan keamanan atas investasi modal yang ditanamkan investor. Peran pemerintah dalam kepemilikan institusional dianggap dapat mengawasi tindakan manajemen dalam menghasilkan kebijakan. Kebijakan manajemen yang dimaksud yaitu termasuk dalam pemilihan auditor independen yang melakukan pemeriksaan laporan keuangan perusahaan.

Badan Pemeriksa Keuangan (BPK) masih menemukan beberapa Kantor Akuntan Publik (KAP) yang tidak melakukan audit laporan keuangan perusahaan BUMN secara benar. Wakil ketua BPK, Hasan Bisri, mengatakan bahwa KAP yang mendapatkan order memeriksa keuangan BUMN harus memahami bahwa pekerjaannya akan dievaluasi BPK. Opini yang menjadi mahkota sebuah KAP dan harga diri seorang auditor haruslah mencerminkan keadaan yang sebenarnya.

Lebih lanjut Hasan Bisri menyatakan bahwa hingga saat ini BPK masih menemukan adanya postur audit yang harusnya dilakukan tapi tidak dilakukan oleh KAP. Hal tersebut akan mempengaruhi opini yang diberikan, sehingga nantinya akan terdapat perbedaan opini yang diberikan oleh KAP dengan BPK (economy.okezone.com, diunduh tanggal 29 Juli 2014).

Berdasarkan latar belakang dan fenomena yang terjadi, penelitian ini ingin mengetahui adanya pengaruh manajemen laba, ukuran dewan komisaris, 
kepemilikan institusional, dan kualitas audit terhadap biaya modal perusahaan BUMN periode 2010 - 2012.

Hasil penelitian ini diharapkan dapat memberikan tambahan pengetahuan dan wawasan, khususnya yang berkaitan dengan bidang akuntansi keuangan, akuntansi manajemen dan pasar modal. Adapun manfaat praktis dari penelitian ini adalah untuk menambah pengetahuan mengenai pengaruh manajemen laba, ukuran dewan komisaris, kepemilikan institusional, dan kualitas audit terhadap biaya modal perusahaan sehingga dapat dijadikan bahan pertimbangan dalam melakukan investasi.

\section{Kajian Pustaka}

Dalam teori keagenan (agency theory), hubungan agensi muncul ketika satu orang atau lebih (principal) memperkerjakan orang lain (agent) untuk memberikan suatu jasa dan kemudian mendelegasikan wewenang pengambilan keputusan kepada agent tersebut (Jensen \& Meckling, 1976).

Agent, atau dalam hal ini adalah pihak yang mengelola perusahaan (manajer), akan bertindak atau melakukan campur tangan dalam proses penyusunan pelaporan keuangan eksternal dengan tujuan untuk memperoleh keuntungan pribadi (Schipper, 1998, dalam Sulistyanto, 2008). Tindakan manajemen tersebut dikenal dengan istilah manajemen laba.

Manajemen laba sangat mungkin dilakukan karena adanya asimetri informasi, di mana manajemen (agents) yang mengelola perusahaan secara langsung lebih mengetahui kondisi perusahaan yang sebenarnya dibandingkan dengan para pemegang saham (principals).

Hubungan principals dan agents dapat menyebabkan terjadinya konflik kepentingan yang berkepanjangan (agency problem). Salah satu mekanisme corporate governance yang dapat digunakan untuk mengendalikan agency problem adalah kepemilikan instistusional (Jensen \& Meckling, 1976). Adanya kepemilikan saham oleh investor institusional diyakini dapat mendorong peningkatan pengawasan yang lebih optimal terhadap kinerja manajemen karena mereka memiliki voting power untuk mengadakan perubahan pada saat manajemen dianggap sudah tidak efektif lagi dalam mengelola perusahaan (Ashbaugh et al, 2004).

Agar proses pengawasan pengelolaan keuangan perusahaan dapat berjalan lebih efektif, diperlukan pihak independen yang berasal dari eksternal perusahaan, misalnya auditor. Auditor akan melakukan proses audit dengan mengumpulkan bukti - bukti yang ada dan kemudian memberikan opini perihal kesesuaian laporan keuangan yang dikeluarkan perusahaan terhadap standar akuntansi keuangan.

Arens et. al (2009) mendefinisikan audit sebagai pengumpulan dan pengevaluasian bukti mengenai suatu informasi untuk menentukan dan melaporkan tingkat kesesuaian antara informasi tersebut dengan kriteria yang telah ditentukan. Berdasarkan International Standards on Auditing (ISA) 200 Alinea 3, tujuan audit adalah mengangkat tingkat kepercayaan dari pemakai laporan keuangan yang dituju, terhadap laporan keuangan itu. Tujuan itu dicapai dengan pemberian opini oleh auditor mengenai apakah laporan keuangan disajikan secara wajar, dalam segala hal yang material, atau memberikan 
gambaran yang benar dan wajar sesuai kerangka pelaporan keuangan yang berlaku.

Kualitas audit yang baik merupakan salah satu faktor pendukung penerapan corporate governance yang baik dimana audit merupakan kendali bagi manajer dalam melaksanakan tugasnya. Kualitas audit dapat didefinisikan sebagai probabilitas auditor akan menemukan dan melaporkan pelanggaran dalam sistem akuntansi klien (DeAngelo, 1981).

Penelitian sebelumnya terkait pengaruh manajemen laba, ukuran dewan komisaris, kepemilikan institusional, dan kualitas audit terhadap biaya modal perusahaan telah dilakukan diantaranya oleh Sari (2009), Chancera (2011), Purwanto (2012), Rebecca \& Siregar (2012), Yunita (2012), Susanto \& Siregar (2012), Kirana (2013) dan Siagian (2013). Penelitian yang dilakukan para peneliti tersebut bertujuan untuk menjelaskan faktor-faktor yang berpengaruh terhadap biaya modal perusahaan.

Manajemen laba digunakan dalam penelitian yang dilakukan oleh Chancera (2011), Purwanto (2012), dan Siagian (2013) dengan menggunakan perusahaan manufaktur yang tercatat di Bursa Efek Indonesia (BEI) sebagai subyek penelitian. Hasil penelitian menunjukkan bahwa manajemen laba berpengaruh positif terhadap biaya modal perusahaan.

Ukuran dewan komisaris digunakan dalam penelitian Sari (2009) dan Susanto \& Siregar (2012). Mereka menduga bahwa ukuran dewan komisaris berpengaruh negatif terhadap biaya modal perusahaan. Hasil penelitian Sari (2009) membuktikan bahwa ukuran dewan komisaris berpengaruh negatif dan signifikan terhadap biaya modal. Hasil berbeda diperoleh Susanto \& Siregar (2012) yang membuktikan bahwa dewan komisaris memiliki pengaruh tidak signifikan terhadap biaya modal.

Kepemilikan institusional digunakan dalam penelitian Sari (2009), Rebecca \& Siregar (2012), dan Yunita (2012). Mereka menduga bahwa kepemilikan institusional berpengaruh negatif terhadap biaya modal perusahaan. Hasil penelitian Sari (2009) menunjukkan bahwa kepemilikan institusional berpengaruh negatif dan signifikan terhadap biaya modal perusahaan. Sementara hasil penelitian yang dilakukan Yunita (2012) membuktikan bahwa kepemilikan institusional berpengaruh positif dan signifikan terhadap biaya modal perusahaan. Hasil penelitian Siregar (2012) menunjukkan bahwa kepemilikan institusional tidak memiliki pengaruh signifikan terhadap biaya ekuitas, sementara kepemilikan institusional berpengaruh negatif terhadap biaya hutang.

Variabel independen yang terakhir digunakan adalah kualitas audit. Variabel kualitas audit digunakan di dalam penelitian yang dilakukan Susanto \& Siregar (2012), Yunita (2012) dan Kirana (2013) dengan menggunakan ukuran Kantor Akuntan Publik (KAP) sebagai indikator untuk mengukur kualitas audit. Hasil penelitian Kirana (2013) dan Yunita (2012) menunjukkan bahwa kualitas audit berpengaruh negatif terhadap biaya modal perusahaan. Sementara hasil penelitian Susanto \& Siregar (2012) menunjukkan bahwa kualitas audit dengan menggunakan ukuran KAP tidak memiliki pengaruh signifikan terhadap biaya modal.

Hasil penelitian yang berbeda atas berbagai hipotesis antar satu peneliti dengan peneliti lainnya mendorong dilakukannya penelitian ini. Perbedaan penelitian ini dengan penelitian sebelumnya terletak pada variasi variabel yang 
diduga berpengaruh terhadap biaya modal perusahaan, subyek penelitian yang digunakan, indikator yang digunakan untuk mengukur setiap variabel, dan periode penelitian. Penelitian ini menggunakan variabel manajemen laba, ukuran dewan komisaris, kepemilikan institusional, dan kualitas audit dengan subyek BUMN periode 2010 - 2012.

Berdasarkan kajian literatur serta beberapa penelitian terdahulu, maka peneliti mengindikasikan manajemen laba, ukuran dewan komisaris, kepemilikan institusional, dan kualitas audit sebagai variabel yang mempengaruhi biaya modal pada BUMN. Adapun hipotesis dari penelitian ini adalah sebagai berikut:

$\mathrm{H}_{1}$ : Manajemen laba berpengaruh positif terhadap biaya modal perusahaan.

$\mathrm{H}_{2}$ : Ukuran dewan komisaris berpengaruh negatif terhadap biaya modal perusahaan.

$\mathrm{H}_{3}$ : Kepemilikan institusional berpengaruh negatif terhadap biaya modal perusahaan.

$\mathrm{H}_{4}$ : Kualitas audit berpengaruh negatif terhadap biaya modal perusahaan.

\section{Metode Penelitian}

Populasi dalam penelitian ini adalah Badan Usaha Milik Negara (BUMN) yang terdaftar di kementerian BUMN periode 2010 - 2012. Metode pemilihan sampel dalam penelitian ini menggunakan teknik purposive sampling. Teknik purposive sampling adalah pemilihan sampel bertujuan, yaitu peneliti kemungkinan mempunyai tujuan atau target tertentu dalam memilih sampel secara tidak acak. Teknik penentuan sampel dilakukan secara tidak acak yang informasinya diperoleh dengan menggunakan pertimbangan tertentu (Indriantoro dan Supomo, 2012). Pertimbangan-pertimbangan dalam penelitian ini antara lain:

1. BUMN yang terdaftar di kementerian BUMN periode 2010 - 2012.

2. BUMN yang mempublikasikan laporan tahunan dan laporan keuangan selama periode 2010 - 2012.

3. BUMN yang membayarkan dividen dan beban bunga secara konsisten selama periode 2010 - 2012.

4. Laporan keuangan yang dipublikasikan menggunakan mata uang Rupiah.

5. Laporan keuangan dan laporan tahunan BUMN tersedia secara lengkap selama periode 2010 - 2012, baik secara fisik maupun melalui website masing masing BUMN.

Berdasarkan pertimbangan tertentu yang telah ditetapkan, dari total pengamatan $141 \mathrm{BUMN}$, diperoleh sejumlah 23 sampel BUMN yang memenuhi pertimbangan. Jumlah BUMN yang memenuhi pertimbangan tersebut dapat di lihat pada tabel 2 .

Tabel 2

Jumlah Pengamatan BUMN

\begin{tabular}{ll}
\hline Jumlah BUMN yang terdaftar tahun 2010 - 2012 & 141 BUMN \\
\hline BUMN yang tidak mempublikasikan laporan tahunan secara konsisten & (81 BUMN) \\
\hline
\end{tabular}




\begin{tabular}{ll}
\hline tahun $2010-2012$ & \\
\hline $\begin{array}{l}\text { BUMN yang tidak membayarkan dividen dan beban bunga secara } \\
\text { konsisten tahun } 2010-2012\end{array}$ & (29BUMN) \\
\hline Laporan keuangan menggunakan mata uang asing & (5 BUMN) \\
\hline Data BUMN yang tidak lengkap & (3 BUMN) \\
\hline Total Sampel Penelitian & 23 Perusahaan \\
\hline
\end{tabular}

Sumber: bumn.go.id dan website masing - masing perusahaan (diolah)

Variabel dalam penelitian ini menggunakan variabel bebas dan terikat. Variabel bebas merupakan variabel yang mempengaruhi atau yang menjadi sebab perubahannya atau timbulnya variabel dependen (terikat) (Sugiyono, 2012). Variabel bebas dalam penelitian ini adalah manajemen laba, ukuran dewan komisaris, kepemilikan institusional, dan kualitas audit.

Manajemen laba merupakan upaya manajer perusahaan untuk mengintervensi atau mempengaruhi informasi-informasi dalam laporan keuangan dengan tujuan untuk mengelabui stakeholder yang ingin mengetahui kinerja dan kondisi perusahaan (Sulistyanto, 2008). Atau dengan kata lain, manajemen laba dapat diartikan sebagai intervensi manajemen perusahaan dalam proses penyusunan laporan keuangan perusahaan yang akan digunakan oleh para pemakai eksternal dengan tujuan untuk menguntungkan kepentingan manajemen perusahaan. Upaya yang dilakukan manajemen tersebut sesuai dengan teori agensi yang menjadi landasan teori dalam penelitian ini.

Variabel manajemen laba dalam penelitian ini diproksikan dengan model spesifik akrual dengan menggunakan margin model yang menekankan pada pengukuran current accruals yaitu akrual yang berasal piutang, beban operasi, dan bad debt (Peasnel et al, 2000).

1. Menentukan akrual modal kerja:

2. Menentukan nilai manajemen laba:

$$
\mathrm{WCi}=(\Delta \mathrm{AL}-\Delta \mathrm{Kas})-\Delta \mathrm{HL}
$$

Keterangan:

$$
\text { Manajemen Laba }(\mathrm{EM})=\frac{\text { Akrual Modal } \operatorname{Kerja}(t)}{\text { Penjualan Periode }(t)}
$$

$\mathrm{WCi}=$ Modal kerja perusahaan, sebagai proksi total akrual pada periode $\mathrm{t}$

$\Delta \mathrm{AL}=$ Perubahan aktiva lancar pada periode $\mathrm{t}$

$\Delta \mathrm{HL}=$ Perubahan hutang lancar pada periode $\mathrm{t}$

$\Delta \mathrm{Kas}=$ Perubahan kas dan ekuivalen kas pada periode $\mathrm{t}$

Ukuran dewan komisaris yang dimaksud pada penelitian ini adalah banyaknya jumlah anggota dewan komisaris dalam suatu perusahaan. Pengukuran dewan komisaris dilakukan dengan menghitung banyaknya jumlah anggota dewan komisaris dalam suatu perusahaan, seperti terlihat dalam formula di bawah ini:

Dewan Komisaris $=\Sigma$ Dewan Komisaris Perusahaan

Kepemilikan institusional merupakan persentase kepemilikan saham perusahaan yang dimiliki oleh investor institusional seperti pemerintah, perusahaan investasi, bank, perusahaan asuransi maupun kepemilikan lembaga dan perusahaan lain (Juniarti dan Sentosa, 2009). Indikator variabel dalam penelitian ini adalah persentase jumlah saham yang dimiliki oleh institusi dari seluruh jumlah modal saham yang dikelola perusahaan. 
Formula dalam mengukur kepemilikan institusional adalah sebagai berikut:

Kepemilikan

Institusional $=\left\{\frac{\text { Jumlah Kepemilikan Saham Institusional }}{\text { Total Saham yang Beredar }} \times 100 \%\right\}$

Kualitas audit yang dimaksud dalam penelitian ini adalah kulitas audit berdasarkan pada opini auditor independen. Opini tersebut diukur dengan menggunakan skala likert dalam point skala 5 mulai dari 1 sampai 5. Setiap item nilai tersebut menunjukkan kesesuaian nilai dengan kualitas auditnya. Semakin tinggi nilai skala menunjukkan nilai tersebut semakin baik kualitas auditnya. Lima tipe opini auditor yang dimaksud adalah Tidak Memberikan Pendapat (Disclaimer of Opinion), Tidak Wajar (Adverse Opinion), Wajar dengan Pengecualian (Qualified Opinion), Wajar Tanpa Pengecualian dengan Bahasa Penjelasan (Unqualified Opinion with Explanatory Language), dan Wajar Tanpa Pengecualian (Unqualified Opinion) (Arens et al, 2009).

Sementara itu, variabel terikat merupakan variabel yang dipengaruhi atau yang menjadi akibat, karena adanya variabel bebas (Sugiyono, 2012). Variabel terikat dalam penelitian ini adalah biaya modal perusahaan. Biaya modal perusahaan merupakan rata-rata tertimbang (weighted average) dari setiap jenis modal yang berbeda yang digunakan perusahaan untuk mendanai kegiatan operasional perusahaan. Perhitungan biaya modal dalam penelitian ini diukur dengan menggunakan biaya modal rata-rata tertimbang (weighted average cost of capital), seperti yang diformulasikan oleh Pratt (2002). Perhitungan biaya modal dengan menggunakan biaya modal rata-rata tertimbang (weighted average cost of capital) adalah sebagai berikut:

$$
W A C C=w_{e} k_{e}+w_{p} k_{p}+w_{d} k_{d}
$$

Keterangan:

$\mathrm{WACC}=$ Biaya modal rata-rata tertimbang periode $\mathrm{t}$;

$w_{e} \quad=$ Proporsi dari common equity di dalam struktur modal;

$k_{e} \quad=$ Cost of common equity periode $\mathrm{t}$;

$w_{p} \quad=$ Proporsi dari jumlah saham preferendi dalam struktur modal;

$k_{p} \quad=$ Cost of preferred equity periode $\mathrm{t}$;

$w_{d} \quad=$ Proporsi dari debt di dalam struktur modal;

$k_{d} \quad=$ Cost of debt periode $\mathrm{t}$;

Penggunaan pinjaman sebagai biaya modal menimbulkan beban tetap. Beban tetap merupakan bunga pinjaman (interest) yang harus dibayarkan perusahaan tanpa melihat profit perusahaan. Bentuk dari utang yang biasa dilakukan oleh perusahaan adalah dengan mengeluarkan surat utang atau obligasi maupun dengan meminjam kepada bank. Cost of debt dihitung dengan persamaan sebagai berikut (Ross et al, 2010):

$$
k_{d}=\frac{\text { Interest Expense }}{\text { Average interest bearing debt }}
$$


Biaya yang muncul ketika perusahaan menggunakan saham preferen sebagai biaya modal adalah pembayaran pendapatan untuk investor yang memberikan dana. Bentuk pendapatan yang diterima investor adalah dalam bentuk pembayaran dividen, tidak dalam bentuk bunga seperti yang didapatkan oleh pemberi pinjaman. Dividen yang didapatkan jumlahnya tetap dan dibayarkan pada periode yang telah ditentukan.

Biaya saham preferen diperhitungkan sebagai berikut (Ross et al, 2010):

$$
k_{p}=\frac{\text { Dividen saham preferen }}{\text { Harga saham preferen }}
$$

Biaya ekuitas mengacu pada tingkat pengembalian yang diinginkan investor atas investasinya di perusahaan tertentu. Biaya ekuitas adalah suatu rate tertentu yang harus dicapai oleh perusahaan untuk dapat memenuhi imbalan yang diharapkan (expected return) oleh para pemegang saham biasa (common stakeholders) atas dana yang telah ditanamkan pada perusahaan tersebut sesuai dengan risiko yang akan diterimanya.

Salah satu cara menghitung biaya ekuitas adalah dengan DDM (Dividend Discount Model). Pada pendekatan DDM, nilai instrinsik dari saham perusahaan didefinisikan sebagai nilai sekarang (present value) dari arus dividen di masa yang akan datang (D1), dan didiskontokan dengan required rate of return dari saham biasa, dan dapat dituliskan sebagai berikut (Ross et al, 2010):

$$
P_{0}=\frac{D_{1}}{\left(1+k_{e}\right)^{1}}+\frac{D_{2}}{\left(1+k_{e}\right)^{2}}+\cdots+\frac{D_{t}}{\left(1+k_{e}\right)^{t}}
$$

Dengan persamaan diatas, maka akan didapat cost of equity $\left(\mathrm{k}_{\mathrm{e}}\right)$ dengan memperkirakan pertumbuhan arus dividen yang akan dibagikan di masa yang akan datang. Besarnya cost of equity $\left(\mathrm{k}_{\mathrm{e}}\right)$ tergantung asumsi yang digunakan mengenai pertumbuhan dividen, sehingga persamaan tersebut dapat dihitung sebagai berikut (Ross et al, 2010):

$$
k_{e}=\frac{D_{1}}{P i}+g_{i}
$$

Penelitian ini menggunakan model data regresi linier berganda dengan tujuan untuk mengetahui pengaruh dua atau lebih variabel bebas terhadap variabel terikat. Model regresi linier berganda ditunjukkan dengan persamaan berikut:

Keterangan:

$$
Y=\alpha+\beta_{1} X_{1}-\beta_{2} X_{2}-\beta_{3} X_{3}-\beta_{4} X_{4+} e
$$

$\mathrm{Y}=$ Biaya Modal Perusahaan

$\mathrm{X}_{1}=$ Manajemen Laba

$\mathrm{X}_{2}=$ Ukuran Dewan Komisaris

$\mathrm{X}_{3}=$ Kepemilikan Institusional

$\mathrm{X}_{4}=$ Kualitas Audit

$\alpha=$ Konstanta

$\beta_{1-4}=$ Koefisien regresi

$\mathrm{e}=$ Error

\section{Hasil dan Pembahasan}

Pengujian hipotesis dilakukan dengan menggunakan analisis regresi berganda. Uji asumsi klasik yang dipersyaratkan untuk model regresi telah 371 | Jurnal Riset Akuntansi dan Keuangan Vol.2 | No.2 | 2014 
dilakukan dan diperoleh hasil sebagai berikut (lihat Lampiran): a) Hasil uji Kolmogorov-Smirnov menunjukkan bahwa nilai Asymp.Sig. (2-tailed) sebesar 0,82. b) Hasil uji multikolinearitas menunjukkan nilai Variance Inflation Factor (VIF) dan Tolerance berada disekitar angka satu, c) Berdasarkan plot dari studentdized residual (sumbu $\mathrm{y}$ ) dan standardized predicted value (sumbu $\mathrm{x}$ ) menunjukkan tidak terbentuknya suatu pola tertentu yang teratur. Hal ini berarti bahwa tidak terjadi heterokedastisitas, d) Hasil uji autokorelasi menunjukkan nilai Durbin-Watson sebesar 2,216. Hal ini berarti tidak terjadi autokorelasi antar variabel.

Hasil penghitungan analisis berganda variabel bebas, yaitu manajemen laba, ukuran dewan komisaris, kepemilikan institusional, dan kualitas audit secara parsial terhadap biaya modal perusahaan dapat di lihat pada tabel 3 di bawah ini:

\section{Tabel 3 \\ Regresi Linear Berganda - Parsial Coefficients $^{\mathrm{a}}$}

\begin{tabular}{|c|c|c|c|c|c|}
\hline \multirow[t]{2}{*}{ Model } & \multicolumn{2}{|c|}{$\begin{array}{l}\text { Unstandardized } \\
\text { Coefficients }\end{array}$} & $\begin{array}{l}\text { Standardized } \\
\text { Coefficients }\end{array}$ & \multirow[t]{2}{*}{$\mathrm{t}$} & \multirow[t]{2}{*}{ Sig. } \\
\hline & B & $\begin{array}{l}\text { Std. } \\
\text { Error }\end{array}$ & Beta & & \\
\hline (Constant) & 36,306 & 3,422 & & 10,609 &, 000 \\
\hline Manajemen Laba & $-2,208$ & ,000 &,- 005 &,- 086 & ,931 \\
\hline 1 Ukuran Dewan Komisaris & ,641 & ,320 & ,118 & 2,001 &, 050 \\
\hline Kepemilikan Institusional &,- 270 & ,019 &,- 846 & $-14,575$ &, 000 \\
\hline Kualitas Audit & ,566 & ,768 & ,042 & ,736 & 464 \\
\hline
\end{tabular}

a. Dependent Variable: Biaya Modal Perusahaan

Hasil koefisien regresi manajemen laba menunjukkan nilai negatif 2,208. Nilai koefisien regresi negatif 2,208 menunjukkan bahwa manajemen laba berpengaruh negatif terhadap biaya modal perusahaan. Hasil negatif tersebut bertentangan dengan hasil penelitian yang telah dilakukan oleh Chancera (2011), Purwanto (2012), dan Siagian (2013) yang menunjukkan bahwa manajemen laba berpengaruh positif terhadap biaya modal perusahaan. Hasil penelitian tersebut mengindikasikan bahwa investor pada perusahaan BUMN belum mengantisipasi dengan benar informasi yang terkait dengan manajemen laba. Sebab semakin tingginya rasio akrual modal kerja terhadap penjualan (proksi manajemen laba) justru akan menurunkan biaya modal perusahaan. Hasil negatif ini juga bertentangan dengan hipotesis dalam penelitian ini.

Ukuran dewan komisaris, yang diukur dengan jumlah komisaris dalam perusahaan, berpengaruh positif terhadap biaya modal perusahaan dengan nilai koefisien regresi positif sebesar 0,641 . Hasil pengaruh positif bertolak belakang dengan hipotesis awal dalam penelitian ini yang menduga adanya pengaruh negatif ukuran dewan komisaris terhadap biaya modal perusahaan. Hasil penelitian yang menunjukkan pengaruh positif ini juga bertolak belakang dengan penelitian Sari (2009) yang membuktikan bahwa ukuran dewan komisaris berpengaruh negatif terhadap biaya modal. Hasil berbeda tersebut dapat terjadi 
karena pada perusahaan BUMN, para investor cenderung melihat fungsi pengawasan yang dilakukan dewan komisaris kurang efektif. Hal ini dapat disebabkan karena banyaknya dewan komisaris yang memiliki hubungan afiliasi dengan perusahaan. Sehingga mengakibatkan rendahnya tingkat independensi dewan komisaris.

Koefisien regresi kepemilikan institusional menunjukkan nilai negatif 0,270. Nilai ini menunjukkan bahwa kepemilikan saham institusional berpengaruh negatif terhadap biaya modal perusahaan. Hasil koefisien regresi yang negatif sesuai dengan hipotesis dalam penelitian ini. Hasil penelitian ini juga mendukung penelitian yang dilakukan oleh Sari (2009) dan Rebecca \& Siregar (2012) yang membuktikan bahwa kepemilikan institusional berpengaruh negatif terhadap biaya modal perusahaan. Kepemilikan institusional berpengaruh secara efektif dalam proses pengawasan terhadap fungsi manajemen. Sehingga laba perusahaan dapat meningkat sesuai dengan yang dilaporkan.

Kualitas audit, yang diukur dengan menggunakan opini auditor independen, berpengaruh positif terhadap biaya modal perusahaan dengan nilai koefisien regresi positif sebesar 0,566 . Hasil pengaruh positif ini bertolak belakang dengan hipotesis awal dalam penelitian ini yang menduga adanya pengaruh negatif kualitas audit terhadap biaya modal perusahaan. Hasil penelitian yang menunjukkan pengaruh positif ini bertolak belakang dengan penelitian Yunita (2012) dan Kirana (2013) yang membuktikan bahwa kualitas audit berpengaruh negatif terhadap biaya modal perusahaan. Hasil yang berbeda tersebut dapat disebabkan dari rendahnya tingkat independensi auditor. Rendahnya tingkat independensi auditor dapat dipengaruhi oleh beberapa faktor, seperti ikatan keuangan dan hubungan usaha, persaingan antar KAP, pemberian jasa lain selain jasa audit, lamanya penugasan audit, serta besaran jumlah fee audit yang diterima auditor sehingga opini yang diberikan oleh auditor independen tersebut dapat menjadi bias.

Sementara itu, nilai koefisien determinasi menurut hasil perhitungan dengan menggunakan software SPPS versi 20 adalah sebesar 0,813 (lihat tabel 4). Nilai ini menunjukkan bahwa variasi manajemen laba, ukuran dewan komisaris,kepemilikan institusional, dan kualitas audit dapat menjelaskan sebesar $81,3 \%$ terhadap variasi biaya modal perusahaan. Sementara $18,7 \%$ lainnya dijelaskan oleh faktor lain yang tidak dibahas dalam penelitian ini.

\section{Tabel 4}

Koefisien Determinasi

Model Summary $\mathbf{b}^{\mathbf{b}}$
\begin{tabular}{|l|r|r|r|c|}
\hline Model & R & R Square & $\begin{array}{c}\text { Adjusted R } \\
\text { Square }\end{array}$ & $\begin{array}{c}\text { Std. Error of the } \\
\text { Estimate }\end{array}$ \\
\hline 1 &, $902^{\mathrm{a}}$ &, 813 &, 802 & 2,75680 \\
\hline
\end{tabular}

a. Predictors: (Constant), Manajemen Laba, Ukuran Dewan Komisaris, Kepemilikan Institusional, Kualitas Audit

b. Dependent Variable: Biaya Modal Perusahaan

373 | Jurnal Riset Akuntansi dan Keuangan Vol.2 | No.2 | 2014 


\section{Simpulan}

Penelitian ini menggunakan variabel manajemen laba, ukuran dewan komisaris, kepemilikan institusional, dan kualitas audit serta pengaruhnya terhadap biaya modal perusahaan. Hasil penelitian menunjukkan bahwa secara parsial, manajemen laba dan kepemilikan institusional berpengaruh negatif terhadap biaya modal perusahaan. Sementara ukuran dewan komisaris dan kualitas audit berpengaruh positif terhadap biaya modal perusahaan.

Hasil koefisien determinasi menunjukkan nilai sebesar 0,813 (81,3\%). Nilai ini menunjukkan bahwa variasi manajemen laba, ukuran dewan komisaris, kepemilikan institusional, dan kualitas hanya dapat menjelaskan sebesar 81,3\% terhadap variasi biaya modal perusahaan. Sementara 18,7\% lainnya dijelaskan oleh faktor lain yang tidak dibahas dalam penelitian ini.

\section{Saran}

Penelitian ini hanya menggunakan 23 sampel BUMN yang terdaftar di Kementerian BUMN periode 2010 - 2012 dengan beberapa pertimbangan yang telah ditetapkan melalui metode purposive sampling. Sehingga hasil penelitian ini tidak dapat digeneralisasi secara luas untuk semua BUMN yang terdaftar di Kementerian BUMN.

Oleh karena itu, peneliti menyarankan agar penelitian selanjutnya menyertakan BUMN dengan jumlah sampel yang lebih banyak dan tahun pengamatan yang lebih panjang agar memperoleh hasil penelitian yang lebih baik.

Selain itu, penelitian selanjutnya juga dapat menggunakan variabel lainnya yang diduga dapat mempengaruhi biaya modal perusahaan, seperti keberadaan komite audit, ukuran perusahaan, dan sebagainya.

\section{Daftar Pustaka}

Agus Purwanto. (2012). Pengaruh Manajemen Laba, Assymetry Information dan Pengungkapan Sukarela Terhadap Biaya Modal. Jurnal Ekonomi Universitas Diponegoro.

Arens, Alvin. A., Elder, Randal J., Beasley, Mark S., \& Amir A. Jusuf. (2009). Auditing and Assurance Services : An Indonesian Adaption. Pearson Prentice Hall.

Ashbaugh, Hollis., Collins, Daniel W.. \& LaFond, Ryan. (2004). Corporate Governance and the Cost Of Equity Capital. Working Paper. www.ssrn.com

DeAngelo, Linda. E. (1981). Auditor Size and Auditor Quality. Journal of Accounting and Economics, 3,00.183-189.

Dhiba Meutya Chancera. (2011). Pengaruh Manajemen Laba Terhadap Biaya Modal Ekuitas Pada Perusahaan Manufaktur Yang Terdaftar Di Bursa Efek Indonesia (BEI) Tahun 2008-2009. Jurnal Ekonomi Universitas Dipenogoro.

Jensen. M. C., \& Meckling, W. H. (1976). Theory of the Firm: Managerial Behavior, Agency Costs and Ownership Structure. Journal of Financial Economics, 3 . 
Juniarti., \& Agnes. A. Sentosa. (2009). Pengaruh Good Corporate Governance, Voluntary Disclosure Terhadap Biaya Utang (Cost Of Debt). Jurnal Akuntansi dan Keuangan, Vol. 11, No.2, November, 88-100.

Mance Tairen Siagian. (2013). Pengaruh Manajemen Laba, Risiko Beta Saham dan Ukuran Perusahaan Terhadap Biaya Modal Ekuitas Perusahaan Manufaktur di Bursa Efek Indonesia. Jurnal Akuntansi Universitas Negeri Medan.

Nancy Yunita. (2012). Pengaruh Corporate Governance terhadap Voluntary Disclosure dan Biaya Hutang. Jurnal Ilmiah Mahasiswa Akuntansi, Vol. 1, No.1, Januari 2012.

Nur Indriantoro., \& Bambang Supomo. (2012). Metodologi Penelitian Bisnis Untuk Akuntansi dan Manajemen. Yogyakarta: BPFE.

Pangestika Ayu Aji Kirana. 2013. Pengaruh Kualitas Audit Terhadap Cost Of Equity Capital. Fakultas Ekonomika dan Bisnis Universitas Diponegoro Semarang.

Peasnell, P., Pope, P., \& Young, S. (2000). "Board monitoring and earnings management: Do outside directors influence abnormal accruals?", working paper, Lancaster University.

Pratt, Shannon P. (2002). Cost of Capital ( $2^{\text {nd }}$ edition). New Jersey: John Wiley \& Sons, Inc.

Putri Arninda Sari. (2009). Pengaruh Corporate Governance Mechanisms Terhadap Cost Of Equity Capital. Skripsi. Tidak dipublikasikan. Universitas Sebelas Maret : Surakarta.

Ross, Stephen., Westerfield, Randolph., \& Jordan, Bradford. (2010). Fundamental of Corporate Finance, 9th Edition. McGraw-Hill : New York.

Siswardika Susanto., \& Sylvia Veronica Siregar. (2012). Corporate Governance, Kualitas Laba, dan Biaya Ekuitas: Studi Empiris Perusahaan Manufaktur Yang Terdaftar Di Bursa Efek Indonesia Tahun 2009. Simposium Nasional Akuntansi XV.

Sri Sulistyanto. (2008). Manajemen Laba; Teori dan Model Empiris. Grasindo : Jakarta.

Sugiyono. (2012). Metode Penelitian Kuantitatif dan Kualitatif dan $R \& D$. Alfabeta.

Yulisa Rebecca., \& Sylvia Veronica Siregar. (2012). Pengaruh Corporate Governance Index, Kepemilikan Keluarga, dan Kepemilikan Institusional Terhadap Biaya Ekuitas dan Biaya Utang. Simposium Nasional Akuntansi $\mathrm{XV}$.

Yunior, W.S. (2009). Pengaruh Kualitas Akrual sebagai Risiko Informasi terhadap Biaya Modal. Skripsi. Fakultas Ekonomi Universitas Indonesia.

International Standards on Auditing (ISA) 200

Kementrian BUMN (www.bumn.go.id)

economy.okezone.com/read/2013/09/12/320/865221/audit-bumn-tak-benar-bpkusul-izin-akuntan-dicabut (diunduh tanggal 29 Juli 2014) 